\title{
Organ Donation in the Context of Brain Death in Muslim Countries: Bioethical Positions
}

\author{
Alqahtani Ibtesam Mohammed \\ King Saud University, School of Nursing; Riyadh 11451, Saudi Arabia \\ Corresponding author: Alqahtani Ibtesam Mohammed; Ibtesam.alqahtani@mymail.barry.edu \\ Received 05 June 2020; \\ Accepted 19 June 2020; \\ Published 03 July 2020
}

\begin{abstract}
One of the miracles of modern medicine for patients with end stage organ failure is organ transplantation. The Organ Procurement and Transplantation Network (OPTN) defines organ donation as giving an organ, tissue, cells, or part of an organ from a living or deceased person (i.e., the donor) to a living person in need (i.e., the recipient). In the last two decades, the number of organ transplants has gradually increased; however, the demand for organ transplantation exceeds the number of available donors. Organs from brain dead donors have been suggested as an alternative option for increasing donation rates when living donors are not available. This article explores the debate surrounding brain death organ donation in Muslim countries. Because organ transplantation is based on Ijtihad, Muslim jurists have no clear-cut text in the Holy Quran or Sunna to use as a foundation for judgment. This has made organ transplants an issue among Muslim scholars and researchers, splitting them into two opinion groups, with one side seeing organ transplantation as legal and the other believing it to be illegal. However, all individuals have the right to choose whether they want to help others by sacrificing parts of themselves and donating their organs. Autonomy, justice, and beneficence must be employed in organ transplantation decision-making.
\end{abstract}

Keywords: Organ Donation, Islamic Ethics, Organ Transplant, Brain Death, Islamic Moral Code.

\section{Background}

One of the miracles of modern medicine for patients with end stage organ failure is organ transplantation. The development of the organ transplantation procedure and the discovery of effective immunosuppressive therapy in the late 1970s vastly increased the success rates of organ transplants. This medical intervention is considered one of the most effective treatment options for saving the lives, and improving the quality of life, of patients affected by terminal organ failures when no other forms of treatment are available. ${ }^{[6]}$ The Organ Procurement and Transplantation Network (OPTN) (2020) defines organ donation as giving an organ, tissue, cells, or part of an organ from a living or deceased person (i.e., the donor) to a living person in need (i.e., the recipient). Organs that can be transplanted from living donors are: blood, bone marrow, pancreases, one kidney, one testis, portions of the liver, portions of the intestines, and the islets of Langerhans. ${ }^{[6]}$ Organs that can be transplanted from deceased donors include: skin, hands, the lungs, kidneys, the heart, testes, heart valves, corneas, the liver, the stomach, blood vessels, intestines, and pancreases. ${ }^{[6]}$ In the last two decades, the number of organ transplants has gradually increased; however, the demand for organ transplantation exceeds the number of available donors. Based on recent OPTN data, over 123,332 people are on the waiting list for lifesaving organs; every ten minutes, another person is added to that list, while the number of donated organs is declining, and deaths on the waiting list are increasing. ${ }^{[8]}$ Studies have emphasized that only a very few people get relief and a second chance at life. Thus, there is an urgent need for more action plans to bridge the gap between supply and demand for organ donation. ${ }^{[8,6,4,3,7]}$

\section{Purpose}

Organs from brain dead donors have been suggested as an alternative option to increase donation rates when living donors are not available. Therefore, this article will explore the debate surrounding brain death organ donation in Muslim countries. The aim is to motivate Muslim communities including families, healthcare professionals, legislative bodies, and religious leaders to overcome potential barriers to discussing and making decisions regarding organ donation.

\section{Material and Method}

A thorough search in the ProQuest Central, PubMed, and PsycINFO databases was conducted using the keywords "organ donation," "Islamic ethics," "organ transplant," "brain death," and "Islamic moral code." Articles were included in this review based on the relevancy of their content to the debate surrounding brain 
death organ donation in Muslim countries. 21 articles were retrieved during the search, and eight were included in the review

\section{Results and Discussion}

Worldwide, Muslims constitute the second largest religious group.$^{[3]}$ Over $22 \%$ of the world population is Muslim an estimated 1.6 billion people. ${ }^{[3]}$ According to Altinörs and Haberal (2016), if $>50 \%$ of a country's total population belong to the Islamic religion, the country is called an Islamic state. Islamic countries include the entire Middle East (except Israel), Central Asia, Northern Africa, and the Far East (Indonesia and Malaysia). ${ }^{[3]}$ Islam is a dynamic religion, and it considers all diseases to be natural phenomena that expiate sins. ${ }^{[4,1]}$ Muslims believe that people who suffer will be rewarded in the hereafter, as will their families who support them. ${ }^{[4]}$ They also believe healing from illness comes only from God, and no cure is possible without God. ${ }^{[4]}$ When physicians declare a condition to be hopeless, numerous Muslims believe in God's miraculous cures. The Prophet Mohammed, Peace Be Upon Him (PBUH), said "O Servants of Allah seek remedy. Allah who caused ailment, also brought cure and redemption". ${ }^{[1,2]}$ In the Islamic context, seeking treatment in certain lifesaving situations may be obligatory, but, in other situations, it may be encouraged, optional, or Haram (meaning not allowed) ${ }^{[1,2]}$ Muslims believe that death occurs by divine decree when the soul departs the body, and it is the beginning of a new journey in a life that is perpetual and infinite. ${ }^{[4]}$ Although the Islamic faith values any methods for saving human lives, organ donation, from either living or deceased donors, remains controversial in Muslim communities.

Muslim jurists make judgments on any issue by following Islam's two primary religious sources: the Holy Quran and the Sunna (the speeches of the Prophet Mohammed, Peace Be Upon Him [PBUH] $).{ }^{[9,1]}$ If jurists are unable to reach a verdict through the Holy Quran and the Sunna, they use reasoning and analogy, which is called Ijtihad. ${ }^{[1]}$ Decisions concerning organ transplantation are based on Ijtihad because Muslim jurists have found no clear-cut text in the Holy Quran or the Sunna to apply to the topic. ${ }^{[1]}$ This has made organ transplantation an issue among Muslim scholars and researchers, dividing them into two opinion groups: one seeing organ transplantation as legal and the other believing it to be illegal.

\section{First Opinion: Permission}

Muslim scholars who believe organ transplantation to be legal are following the opinion of the Islamic Fiqh Academy, the Committee of the Grand Ulama of the Kingdom of Saudi Arabia, and the Fatwa Committees in Islamic countries. ${ }^{[1]}$ They base their permissiveness on many religious justifications, including the following. Organ transplantation is a treatment that has proven successful for serious diseases threatening human life, and, hence, it should be applied. ${ }^{[1]}$ Making things easier for human beings, pitying the sick, and sharing others' pain are mentioned in numerous verses of the Holy Quran: for example, "Allah intends for ease, and He does not want to make things difficult for you," and "If anyone saved a life, it would be as if he saved the life of the whole people". ${ }^{9,1]}$

Another argument for supporting organ transplantation holds that it is a type of cure that has saved human lives, and the Shari'ah (Islamic law) has permitted cure under the principle that necessity overrides prohibition in cases of utmost need. ${ }^{[9,1]}$ This opinion is supported by the Holy Quran's explicitly allowing people to eat carcasses, pork, or blood when in need: "He hath only forbidden you dead meat, and blood, and the flesh of swine, and that on which any other name hath been invoked besides that of Allah. But if one is forced by necessity, without willful disobedience, nor transgressing due limits, then is he guiltless. for Allah is Oft-forgiving Most Merciful". [1]

Again, in favor of organ transplantation, some argue that humans should always keep their dignity, even in diseases, and should always seek remedy. ${ }^{[1]}$ Treatment should cause no harm, or minimal harm in comparison to its benefit. ${ }^{[9,1]}$ In the Holy Quran, God said: "Behold thy Lord said to the Angels: I will create a vicegerent on earth"; "We have honored the progeny of Adam"; He also said "Every soul will be held responsible for what it had done" ${ }^{[1]}$ According to these verses, living donors cannot give one of their vital organs, which would end their lives, because that would be considered homicide or suicide from the Islamic perspective. ${ }^{[9,1]}$ Organ donation should cause no harm or minimal risk to the donor's health. The harm of illness, which includes human death, cannot be compared to the harm that may result from a donation. ${ }^{[9,1]}$ Dying people do not need their vital organs as much as persons on waiting lists, who could be saved from death by an organ transplant. ${ }^{[9]}$ Giving the gift of life to another human being is considered a charitable act, which is known in Islam as In istihsan, meaning seeking to do good. ${ }^{[9]}$

\section{Second Opinion: Prohibition}

Muslim scholars who believe organ transplantation to be illegal include Sheikh Hassan al-Saqqaf, Sheikh Muhammad alSha'arawi, and Dr. Hassan al-Shadhili. ${ }^{[1]}$ They base their prohibition on many religious justifications, including the following. The dignity of human beings' bodies, living or dead, should always be kept and respected. ${ }^{[4,9,1]}$ When a man broke the bone of a deceased person, Prophet Mohammed, Peace Be Upon Him (PBUH), rebuked the man and said: "Breaking the bones of a dead man is similar to breaking the bones of a living man". ${ }^{[1]}$ Individuals are entrusted with their bodies, which are the property of God; they should use them in proper ways, as prescribed by Allah and His Messenger. ${ }^{[4,1]}$ Prophet Mohammed, Peace Be Upon Him (PBUH), said "do not maim". ${ }^{[1]}$ Hence, the transplanting of the organ from a living or deceased body is an act of transgression against the body and violates the body's sanctity. This act of mutilation will be judged and punished by God on the day of judgment. ${ }^{[4,1]}$

Various Muslim scholars have also rejected brain death organ transplantation because brain death is incompatible with the Quranic description of death, which states that death must be proved with absolute certainty. ${ }^{[4,9]}$ Such scholars argue that organ transplantation is supposed to be performed with no general anesthesia because donors are presumed to be dead, but, in fact, most surgeons use general anesthesia for brain dead individuals when procuring organs. ${ }^{[4]}$ Because the medical brain death criterion cannot prove death with absolute certainty, the continuity of an individual's life should be presumed until death is confirmed. ${ }^{[9]}$ Without evidence-based certainty, death should not be declared in a living person, and organ donation, in such cases, transgresses the Islamic moral code, which intends to protect an individual's life. ${ }^{[4,9]}$

\section{Bioethical Principles}

Organ donation is based on the pillars of altruism as coined by Auguste Comte, the French founder of positivism. ${ }^{[5]}$ Altruism is defined as a moral duty to help others, which is a core element of Islamic principles. Individuals' actions are considered altruistic when their moral value is primarily focused on beneficially impacting others, without regarding the consequences of the actions on the actors themselves. ${ }^{[5]}$ The opposite of altruism is 
egoism, which is defined as the sense of self-importance. ${ }^{[5]}$ However, all individuals have the right to choose whether they want to help others and sacrifice parts of themselves by donating their organs. ${ }^{[5]}$ Autonomy, justice, and beneficence must be employed in organ transplantation decision-making. ${ }^{[5]}$ Saving individuals' lives must be the essential goal of all healthcare interventions. In organ transplant situations, it is crucial to assess the risk-benefit ratio for the donor and the recipient. The equality of human beings must also be respected. ${ }^{[5]}$ Though there is a religious debate surrounding accepting organ donations, healthcare providers are responsible for adhering to medicine's moral obligations. One of these obligations is the commitment to do no harm. ${ }^{[5]}$ This principle is the most serious ethical concern for living or brain dead organ donors due to the potential of causing them medical harm. All healthcare providers have the duty of beneficence. Hence, they are obligated to benefit their patients and place patient wellbeing before anything else. Fiduciary responsibility obligates healthcare providers to use their knowledge and experiences for their patients' good. ${ }^{[5]}$

\section{Author's Perspective}

Consider the following scenario. Abeer was a 22-year-old lady, who was transferred to the emergency room (ER) suffering cardiac arrest after a car accident. Before she reached the hospital, cardiopulmonary resuscitation was initiated. When she arrived at the ER, hypothermia protocol and life support measures were begun. A computed tomography (CT) scan was also conducted, which showed that Abeer had sustained serious brain injuries and severe intracranial bleeding. The physicians decided to transfer Abeer to the intensive care unit (ICU). She remained comatose, and a neurosurgeon neurologically examined her several times. Eight months before this happened, Abeer graduated from Science College and began her job as an elementary school teacher. She suffered from no medical diseases, and she was a very kind, intelligent, open-minded, and tolerant person, who always stood up for others. Abeer dreamed of being an independent, successful lady and of getting married and becoming a great mother, but, unfortunately, this accident stole her life and her dreams. In February 2013, the author saw Abeer her childhood friend and her uncle's daughter lying there on the ICU bed. It was one of the worst memories the author can recall. The author prayed to God to make Abeer well again, but the reality was that the doctors pronounced her brain dead. The author's heart was truly breaking. Lengthy discussions and negotiations between the healthcare providers and Abeer's parents took place. The family decided to stop ventilatory support and rejected the idea of organ donation. This loss is tragic, but the family members' objections to organ donation stemmed from the fact that they believe in body integrity after death. However, this author believes that traffic accidents are a serious problem worldwide and that cars may take anyone's life at any time. Hence, this author would not desire to leave patients like Abeer connected to a ventilator machine, and also this author believes that there are many people in this world waiting to hear that a suitable donor organ has been found for them. Organ donation is a lifesaving action. It is a privilege to make a difference in the lives of others by giving them the chance to lead healthy lives and move forward in this journey without suffering. Therefore, the author believes that the only way to facilitate change in organ donation is by example. Thus, after such a tragic loss in her own family, the author signed the organ donation card in 2013. Author's decision might not make much of a difference, but one spark can light a fire.

\section{Recommendations}

The idea of organ donation in Muslim countries requires more attention and effort to promote it as a positive action. Most importantly, healthcare providers should bring up organ donation only after families accept that their relative has died. Allowing a time for families to come together to begin their grief process could change their decisions about organ donation. Equally important is the need to cooperate with religious leaders to increase societal awareness about the principles of organ donation. During such difficult circumstances, giving a patient's family members the opportunity to consult with a religious leader about organ donation is important for helping them make the best decision. Using social media to promote the organ donation concept is another way to encourage individuals to think more deeply about this topic. Establishing educational sessions in public may also help encourage more people to carry donor cards.

\section{References}

[1] Albar, M. A. (1996). Islamic ethics of organ transplantation and brain death. Saudi Journal of Kidney Diseases and Transplantation, 7(2), 109.

[2] Albar, M. A. (2007). Seeking remedy, abstaining from therapy and resuscitation: An Islamic perspective. Saudi Journal of Kidney Diseases and Transplantation, 18(4), 629.

[3] Altınors, N., \& Haberal, M. (2016). Brain death and transplant in Islamic countries. Experimental and Clinical Transplantation, 3, 48-52.

[4] Chamsi-Pasha, H., \& Albar, M. A. (2017). Do not resuscitate, brain death, and organ transplantation: Islamic perspective. Avicenna Journal of Medicine, 7(2), 35.

[5] Dalal, A. R. (2015). Philosophy of organ donation: Review of ethical facets. World Journal of Transplantation, 5(2), 44.

[6] Job, K., \& Antony, A. (2018). Organ donation and transplantation: "Life after death." In G. Tsoulfas (Ed.), Organ donation and transplantation: Current status and future challenges (pp. 17-32). IntechOpen.

[7] Moritsugu, K. P. (2013). The power of organ donation to save lives through transplantation. Public Health Reports, 128(4), 245-246.

[8] Organ Procurement and Transplantation Network (OPTN). (2020). Data. Organ Procurement and Transplantation Network: U.S. Department of Health \&HumanServices. https://optn.transplant.hrsa.gov/data/

[9] Rady, M. Y., \& Verheijde, J. L. (2014). The moral code in Islam and organ donation in Western countries: Reinterpreting religious scriptures to meet utilitarian medical objectives. Philosophy, Ethics, and Humanities in Medicine, 9(1), 11.

\section{Author Profile}

Alqahtani Ibtesam received a B.S. degree in Nursing from King Saud University in the Kingdom of Saudi Arabia, and received an M.S degree in Nursing Education from Roberts Wesleyan College in the United States of America respectively. Currently, she is completing her $\mathrm{PhD}$ in Nursing at Barry University in the state of Florida, the United States of America. 